\title{
RADIOCARBON DATING OF VARVE CHRONOLOGIES: SOPPENSEE AND HOLZMAAR LAKES AFTER TEN YEARS
}

\author{
Irka Hajdas • Georges Bonani \\ Institut für Teilchenphysik, ETH Hönggerberg, 8093 Zurich, Switzerland. Email: hajdas@ particle.phys.ethz.ch. \\ Bernd Zolitschka \\ Geomorphologie und Polarforschung (GEOPOL), Institut für Geographie, Universitaet Bremen, Celsiusstr. FVG-M, \\ D-28359 Bremen, Germany
}

\begin{abstract}
During the last decade, several radiocarbon-dated varve chronologies have been produced. The main goal at first was the extension of the ${ }^{14} \mathrm{C}$ calibration curve beyond 10,000 BP. This paper aims to discuss varve chronologies of Soppensee and Holzmaar Lakes. Although both chronologies encountered problems, high-resolution ${ }^{14} \mathrm{C}$ dating and relative varve time have been obtained for events during the Late Glacial.
\end{abstract}

\section{INTRODUCTION}

Twenty years ago, Bernd Becker and Bernd Kromer were working on a link between German oak and pine in order to extend the tree-ring calibration curve (Becker and Kromer 1986). Around that time, a series of samples consisting of terrestrial macrofossils, which were preserved in sediments, were dated by accelerator mass spectrometry (AMS) (Andrée et al. 1986; Zbinden 1987; Zbinden et al. 1989). This showed that variations in the atmospheric ${ }^{14} \mathrm{C}$ content of the past could be reconstructed by dating terrestrial macrofossils. Laminated lake sediments were considered to be most suitable for precise dating. Sediments recovered from Soppensee, a small lake in Switzerland, appeared to contain varves (annual laminations) and sufficient amounts of terrestrial macrofossils (Lotter 1989). Laminations were present in the Late Glacial (LG) part of the record and the first 3000 years of the Holocene. Varve chronologies were constructed, and terrestrial macrofossils were dated and combined to a ${ }^{14} \mathrm{C}$-varve chronology. Because the laminations in the $\mathrm{LG}$ part of the record were not continuous, corrections had to be applied to the varve chronology (Hajdas et al. 1993).

The varve chronology of Lake Holzmaar (Germany) has been developed earlier and independently of the Soppensee chronology (Zolitschka 1990). ${ }^{14} \mathrm{C}$ dating of the Holzmaar record seemed to be a sufficient cross-check for the Soppensee chronology. In both records, a layer of ash from a volcanic eruption of the Laacher See (LST) was present. This allowed the correlation of these records. After correcting the late Holocene sediments of the Holzmaar varve chronology, both records showed a close correlation (Hajdas 1993). During the last ten years, new records have been established, refining the dating of the LG period (Goslar et al. 1995; Hughen et al. 1998a, 1998b). Here we present an assessment of an error in the varve chronologies for both the Soppensee and Holzmaar records. ${ }^{14} \mathrm{C}$ chronologies remain valid and allow reconstruction of atmospheric ${ }^{14} \mathrm{C}$ variations during the $\mathrm{LG}$.

\section{Soppensee}

The ${ }^{14} \mathrm{C}$ time scale for sediments of Soppensee is based on AMS dating of terrestrial macrofossils. High resolution ${ }^{14} \mathrm{C}$ dating was performed on sediments between 7000 and 10,000 BP. Because the sediment in Soppensee is not laminated from the top, a floating ${ }^{14} \mathrm{C}$-varve chronology was constructed. Fifty ${ }^{14} \mathrm{C}$ dates were paired with relative varve ages and were matched to the calibration curve in order to establish the absolute time scale. The chronology beyond 10,000 BP was based on $31{ }^{14} \mathrm{C}$ dates and a corrected varve chronology (Hajdas et al. 1993). Figure 1 shows the Soppensee ${ }^{14} \mathrm{C}$ varve chronology, plotted with the most recent tree-ring chronology (Kromer and Spurk 1998). The agreement between the Holocene part of the varve chronology and the tree rings shows that the combination of varve chronologies and ${ }^{14} \mathrm{C}$ dating of terrestrial macrofossils can be used for precise 
time control. The ${ }^{14} \mathrm{C}$ plateaux at $8250,8750,9600$, and $10,000 \mathrm{BP}$ are clearly reproduced in the Soppensee chronology. Earlier in 1993, there was an indication in the varve chronology for a plateau at 8900 BP (Hajdas 1993). Also, the younger flank of the 10 ka plateau in the Soppensee chronology suggested a need for a correction of the tree-ring chronology at the time (Hajdas 1993). Problems in the Soppensee record arise at the Younger Dryas (YD) biozone and the presence of unlaminated segments in this part of the record. Correction for their presence was based on an estimation of the sedimentation rate. This resulted in a number of 550 varves, that had to be added to the YD biozone. The duration of the YD in the Soppensee was very close to the duration found in the GRIP ice core (1150 yr; Johnsen et al. 1992) and the Gościąż varve chronology (1140 yr; Goslar et al. 1995). Therefore, at that time, it appeared that our correction for unlaminated sediments was adequate. Figure 1 shows the chronology, with boundaries of the YD biozone as defined by palynology. The Younger Dryas/Preboreal (YD/PB) boundary in Soppensee is about 600 years younger than the same boundary dated in other European records (Goslar et al. 1995; Björck et al. 1996). As a result, a part of the European Preboreal (PB) was included into our YD chronology and obscured underestimation of the correction discussed above. As shown in Figure 1, additional 500-600 years should be included in the Soppensee chronology of the YD biozone. This correction in the Soppensee chronology now results in an age of 12,850 cal BP for an age for the LST layer. A similar age of 12,880 cal BP for the LST is determined by recent dating of the Meerfelder Maar (MFM) varve chronology and deduced from the dating of the YD boundaries in ice cores of Greenland (Brauer et al. 1999; Brauer et al. this issue; von Grafenstein et al. 1999).

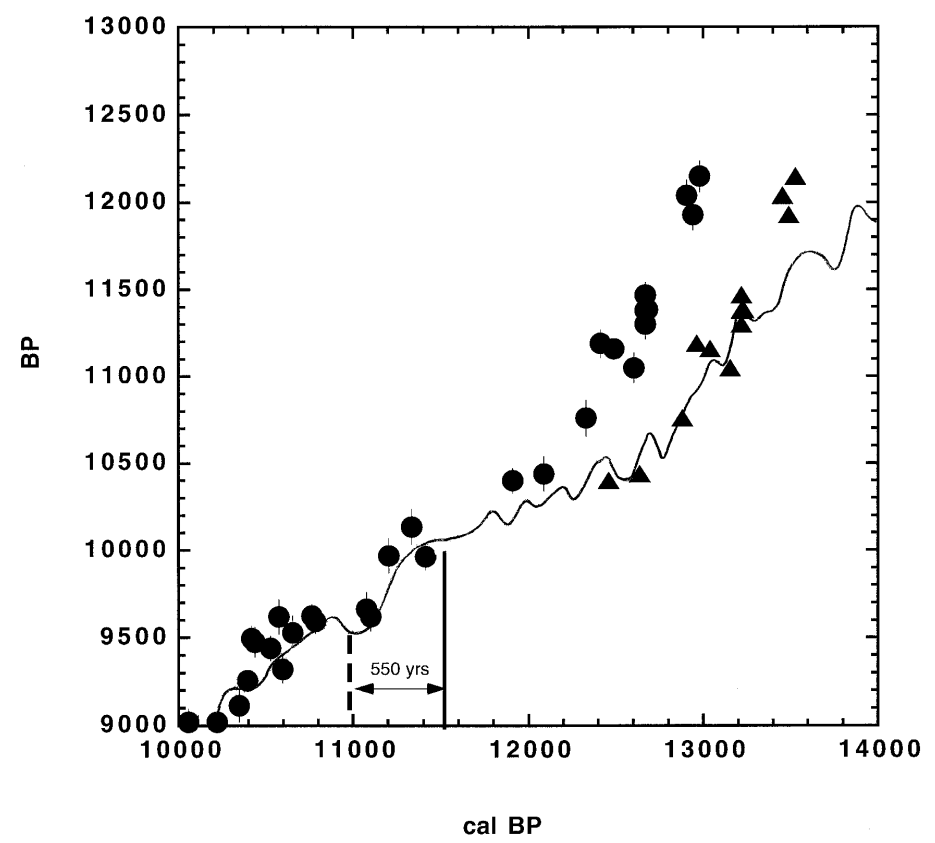

Figure 1 Soppensee ${ }^{14} \mathrm{C}$-varve chronology (filled circles) plotted with INTCAL98 (all the points with one sigma uncertainty) (Stuiver et al. 1998). The solid line marks the end of the YD according to the European records at 11,550 cal BP (see text). The line through the data points shows the end of the YD biozone as defined in Soppensee at 10,986 cal BP. Triangles show the Soppensee chronology with additional $550 \mathrm{yr}$ added to all the points beyond $12,000 \mathrm{cal} \mathrm{BP}$. 


\section{Holzmaar}

Terrestrial macrofossils were washed from the sediment and ${ }^{14} \mathrm{C}$ dated using AMS. Next, the ${ }^{14} \mathrm{C}$ ages were paired with the corresponding varve time as published by Zolitschka (1990). The sediment in the Holzmaar cores is laminated from the top, but comparison of the ${ }^{14} \mathrm{C}$-varve chronology with the calibration curve yielded an error in the varve chronology of the late Holocene. The shift between 2000 and 3838 cal BP has been corrected for 878 varve years; the rest of the Holocene remained in very good agreement with the tree-ring chronology (Hajdas et al. 1995). Although the Holzmaar chronology was concordant with the Soppensee chronology, there was a difference in duration of the YD. The YD in Holzmaar was defined by a change in sediment: 550 yr $(11,940$ $11,490 \mathrm{cal} \mathrm{BP}$ ), i.e. about $600 \mathrm{yr}$ shorter than the YD in the GRIP ice core and the Lake Gościąz sediments (Johnsen et al. 1992; Goslar et al. 1995). Additional samples were dated to identify the $10 \mathrm{ka}$ and 9.5 ka plateaux (Table 1) in the Holzmaar chronology. Recently, the varve chronology of Holzmaar has been corrected for varves missing in the YD biozone, i.e. beyond the YD/PB transition, which was dated to be $11,490 \mathrm{cal} \mathrm{BP}$ (Hajdas et al. 1995). Also, new pollen analysis showed that varves were missing inside the YD biozone (Leroy et al. 2000), suggesting the need for a correction of 320 varves beyond $12,025 \mathrm{cal} \mathrm{BP}$.

Table 1 AMS ${ }^{14} \mathrm{C}$ dates obtained on macrofossils selected from Holzmaar sediment core in order to reconstruct $10,000 \mathrm{BP}$ plateau

\begin{tabular}{cclccl}
\hline $\begin{array}{c}\text { Lab nr } \\
(\text { ETH- })\end{array}$ & $\begin{array}{c}\text { Sample } \\
(\text { HZM- })\end{array}$ & Core depth & $\begin{array}{c}{ }^{14} \mathrm{C} \text { age } \\
(\mathrm{BP})\end{array}$ & $\begin{array}{c}\delta^{13} \mathrm{C} \\
(\mathrm{PDB} \% \text { ) }\end{array}$ & Material dated \\
\hline 13503 & 40 & 871.3 & $9550 \pm 80$ & $-23.1 \pm 1.2$ & Bark \\
13504 & 41 & 876 & $9665 \pm 100$ & $-24.7 \pm 1.2$ & Bark, seeds, catkin scale, needle fragments \\
13505 & 42 & 878.8 & $9565 \pm 110$ & $-21.4 \pm 1.3$ & Seeds, bark \\
13506 & 43 & 886 & $9830 \pm 100$ & $-20.6 \pm 1.3$ & Needle, bark, seeds \\
13507 & 44 & 890.5 & $9805 \pm 190$ & $-19.0 \pm 1.5$ & Bark \\
13508 & 45 & 895 & $9905 \pm 80$ & $-28.7 \pm 1.2$ & Bark \\
13509 & 46 & 897.5 & $10,060 \pm 80$ & $-27.8 \pm 1.3$ & Macrofossils: bark, seeds, catkin scale \\
13510 & 47 & 899.9 & $10,110 \pm 110$ & $-24 \pm 1.2$ & Macrofossils: bark, seeds, needle \\
13511 & 48 & 903.7 & $11,040 \pm 140$ & $-17.1 \pm 1.2$ & Macrofossils \\
13512 & 49 & 920.2 & $10,090 \pm 85$ & $-26.0 \pm 1.2$ & Macrofossils: needles, Betula seeds, catkin \\
& & & & & scale, piece of wood or bark \\
13513 & 50 & 929.7 & $10.080 \pm 110$ & $-24.1 \pm 1.2$ & Macrofossils: twig fr., needle fr., leaf fr. \\
13514 & 51 & 942 & $10,350 \pm 90$ & $-26.2 \pm 1.3$ & Macrofossils: twig, small pieces of needles, \\
& & & & & well-preserved bark \\
\hline
\end{tabular}

In Figure $2,{ }^{14} \mathrm{C}$ dates are plotted together with the newly corrected varve ages (Zolitschka, forthcoming). When compared with the INTCAL98 recommended calibration curve (Stuiver et al. 1998), this correction still appears to be an underestimation, but a better agreement has been obtained with all other chronologies of the LG. The best illustration of the agreement with the GRIP ice core chronology is the age of the LST layer. Brauer et al. (1999) demonstrated that the varve chronology of lake MFM dates the LST to 12,880 cal BP. The eruption of the Lacheer See preceded the YD cooling by some 200 years (Hajdas et al. 1995). Therefore, the age of the LST should be between 12,800 and 13,000 cal BP, based on the timing of the Alleröd/Younger Dryas (AL/YD) transition as found in both the GRIP and GISP2 ice cores. The calibrated age of the LST ranges between 13,000 and 13,200 cal BP (the ${ }^{14} \mathrm{C}$ date is $11230 \pm 40 \mathrm{BP}$ ). The difference of about 200 years between European records (MFM, Gościąż) and calibrated age of the LST corresponds to the difference in length of the YD in GRIP and GISP2, 1150 and 1300 years, respectively. The INTCAL98 calibration data, which are based on U/Th dated corals and Carioco basin varve chro- 


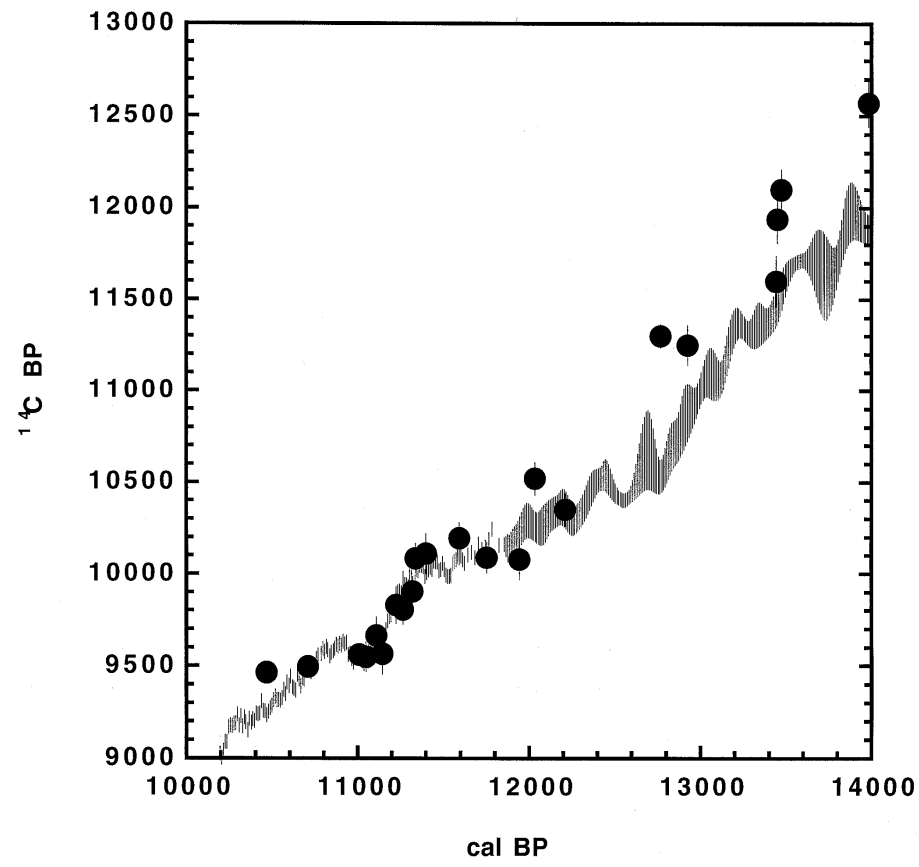

Figure 2 Holzmaar ${ }^{14} \mathrm{C}$ chronology plotted against the corrected varve chronology (Zolitschka, forthcoming) and the INTCAL98 calibration curve (Stuiver et al. 1998). Additional ${ }^{14} \mathrm{C}$ dates were obtained to reconstruct the ${ }^{14} \mathrm{C}$ plateau at 10,000 BP (Table 1).

nology (Stuiver et al. 1998), are closer to the GISP2 chronology. However, the agreement between European records and the GRIP chronology is striking (Brauer et al. 1999; von Grafenstein et al. 1999; Goslar et al. 2000). Nevertheless, the difference in the YD duration as well as dating of the YD boundaries in both ice cores should be minimized.

\section{CONCLUSION}

The chronologies of both Soppensee and Holzmaar represent the first attempts to extend the calibration curve by using varve chronologies. Both lake records contributed to a chronology of the last deglaciation and to the reconstruction of the atmospheric ${ }^{14} \mathrm{C}$ content, despite problems as discussed in this paper. This was only possible because of the high-resolution ${ }^{14} \mathrm{C}$ dating of these records. Characteristic features of the ${ }^{14} \mathrm{C}$ calibration curve (such as plateaux) can also be seen in unlaminated sediments and can be used for correlation between records and dating of events (Hajdas et al. 1998). Therefore it seems that ${ }^{14} \mathrm{C}$ dating is a necessary assessment for all varve chronologies. Further extension of the ${ }^{14} \mathrm{C}$ calibration curve will require ${ }^{14} \mathrm{C}$ dating of a perfectly laminated record. Although perfect laminations exist, only an agreement between many sites can result in a final calibration curve. 


\section{REFERENCES}

Andrée M, Oeschger H, Siegenthaler U, Ammann B, Tobolski K. $1986 .{ }^{14} \mathrm{C}$ dating of macrofossils in lake sediments. Radiocarbon 28(2A):411-6.

Becker B, Kromer B. 1986. Extension of the Holocene dendrochronology by the Preboreal pine series, 8800 to 10,100 BP Radiocarbon 28(2B):961-7.

Björck S, Kromer B, Johnsen S, Bennike O, Hammarlund D, Lemdahl G, Possnert G, Rasmussen TL, Wohlfarth B, Hammer CU, Spurk M. 1996. Synchronized terrestrial-atmospheric deglacial records around the North Atlantic. Science 274:1155-60.

Brauer A, Endres C, Gunter C, Litt T, Stebich M, Negendank J. 1999. High resolution sediment and vegetation responses to Younger Dryas climate change in varved lake sediments from Meerfelder Maar, Germany. Quaternary Science Reviews 18:321-9.

Brauer A, Endres C, Zolitschka B, Negendank JFW. 2000. AMS radiocarbon and varve chronology from the annually laminated sediment record of lake Meerfelder Maar, Germany. Radiocarbon. This issue.

Goslar T, Arnold M, Bard E, Kuc T, Pazdur M, RalskaJasiewiczowa M, Rozanski K, Tisnerat N, Walanus A, Wicik B, Wieckowski K. 1995. High concentration of atmospheric ${ }^{14} \mathrm{C}$ during the Younger Dryas. Nature 377:414-7.

Goslar T, Arnold M, Tisnerat LN, Czernik J, Wieckowski K. 2000. Variations of Younger Dryas atmospheric radiocarbon explicable without ocean circulation changes. Nature 403:877-80.

Hajdas I. 1993. Extension of the radiocarbon calibration curve by AMS dating of laminated sediments of lake Soppensee and lake Holzmaar. Diss. ETH Nr.10157, ETH Zurich.

Hajdas I, Bonani G, Boden P, Peteet DM, Mann DH. 1998. Cold reversal on Kodiak Island, Alaska, correlated with the European Younger Dryas by using variations of atmospheric C-14 content. Geology 26: 1047-50.

Hajdas I, Ivy SD, Beer J, Bonani G, Imboden D, Lotter AF, Sturm M, Suter M. 1993. AMS radiocarbon dating and varve chronology of lake Soppensee: 6000 to $12,000{ }^{14} \mathrm{C}$ years BP. Climate Dynamics 9:107-16.

Hajdas I, Ivy SD, Bonani G, Lotter AF, Zolitschka B, Schlüchter C. 1995. Radiocarbon age of the Laacher See Tephra: 11,230 \pm 40 BP. Radiocarbon 37(2):149 54

Hajdas I, Zolitschka B, Ivy SD, Beer J, Bonani G, Leroy SAG, Ramrath M, Negendank JFW, Suter M. 1995.
AMS radiocarbon dating of annually laminated sediments from lake Holzmaar, Germany. Quaternary Science Reviews 14:137-43.

Hughen KA, Overpeck JT, Lehman SJ, Kashgarian M, Southon JR. 1998a. A new ${ }^{14} \mathrm{C}$ calibration data set for the last deglaciation based on marine varves. Radiocarbon 40(3):1483-94.

Hughen KA, Overpeck JT, Lehman SJ, Kashgarin M, Southon J, Peterson LC, Alley R, Sigman DM. 1998b. Deglacial changes in ocean circulation from an extended radiocarbon calibration. Nature 391:65-8.

Johnsen SJ, Clausen HB, Dansgaard W, Iversen P, Jouzel J, Stauffer B, Steffensen JP. 1992. Irregular glacial interstadials recorded in a new Greenland ice core. $\mathrm{Na}$ ture 359:311-3.

Kromer B, Spurk M. 1998. Revision and tentative extension of the tree-ring based ${ }^{14} \mathrm{C}$ calibration, 920011,855 cal BP. Radiocarbon 40(3):1117-25.

Leroy S, Zolitschka B, Negendank J, Seret G. 2000. Palynological analyses in the laminated sediment of Lake Holzmaar (Eifel, Germany): duration of Lateglacial and Preboreal biozones. Boreas 29:52-71.

Lotter AF. 1989. Evidence of annual layering in Holocene sediments of Soppensee, Switzerland. Aquatic Sciences 52:19-30.

Stuiver M, Reimer PJ, Bard E, Beck JW, Burr GS, Hughen KA, Kromer B, McCormac G, van der Plicht J, Spurk M. 1998. INTCAL98 radiocarbon age calibration, 24,000-0 cal BP. Radiocarbon 40(3):104183.

von Grafenstein U, Erlenkeuser H, Brauer A, Jouzel J, Johnsen SJ. 1999. A mid-European decadal isotopeclimate record from 15,500 to 5000 years BP. Science 284:1654-7.

Zbinden H. 1987. ${ }^{14}$ C Messungen an Pflanzenresten aus Sediment. Universität Bern: Physikalisches Institut.

Zbinden H, Andrée M, Oeschger H, Ammann B, Lotter A, Bonani G, Wölfli W. 1989. Atmospheric radiocarbon at the end of the Last Glacial: an estimate based on AMS radiocarbon dates on terrestrial macrofossils from lake sediment. Radiocarbon 31(3):795-804.

Zolitschka B. 1990. Spätquartäre Jahreszeitlich geschichtete Seesedimente ausgewählter Eifelmaare. Documenta Naturae 60:1-226.

Zolitschka B, Brauer A, Negendank JFW, Stockhausen $\mathrm{H}$, Lang A. Annually dated late Weichselian continental paleoclimate record from the Eifel, Germany. $G e$ ology 28(9):783-86. 